\title{
Uncomplicated spontaneous rupture of the pancreatic pseudocyst into the duodenum: Case report
}

\section{Pankreatik psödokistin duodenuma komplikasyona yol açmayan spontan rüptürü: Olgu sunumu}

\begin{abstract}
Ali Emre Atıcı*, Mustafa Duman, Enver Reyhan, İlter Özer, Tahsin Dalgıç, Erdal Birol Bostancı, Musa Akoğlu

Departments of General and Gastrointestinal Surgery (A. E. Atıc1, MD), Dr. Lütfi Kırdar Education and Research Hospital, TR-34746 İstanbul, Departments of Gastrointestinal Surgery (M. Duman, MD), Kartal Koşuyolu Yüksek İhtisas Education and Research Hospital, TR-34846 İstanbul, Departments of General Surgery (E. Reyhan, MD), Adana Numune Education and Research Hospital, TR-01030 Adana, Departments of Gastrointestinal Surgery (Assoc. Prof. İ. Özer, MD, T. Dalgıç, MD, E. B. Bostancı, MD, M. Akoğlu, MD), Türkiye Yüksek İhtisas Education and Research Hospital, TR-06230 Ankara
\end{abstract}

\begin{abstract}
Pancreatic pseudocyst is one of the common complications of acute and chronic pancreatitis. Although most pseudocysts resolve spontaneously with supportive care, larger pseudocysts are more likely to cause complications. Large pancreatic pseudocysts may rupture spontaneously into the gastrointestinal tract and are usually associated with life-threatening bleeding. Surgical treatment or interventional drainage procedures may be necessary. Uncomplicated rupture of pseudocyst is extremely rare.
\end{abstract}

Keywords: Acute pancreatitis, pseudocyst, spontaneous rupture

\section{Özet}

Pankreatik psödokistler akut ve kronik pankreatitin sık görülen komplikasyonlarından biridir. Çoğu psödokistler destek tedavisi ile spontan regrese olmasına rağmen, büyük psödokistlerin çeşitli komplikasyonlara yol açması daha fazla olasıdır. Gastrointestinal sisteme spontan rüptüre olabilirler ve genellikle yaşamı tehdit eden gastrointestinal system kanamalarına yol açabilirler. Tedavilerinde cerrahi yada girişimsel drenaj prosedürleri gerekli olabilir. Pankreatik psödokistlerin komplikasyona yol açmayan spontan rüptürleri son derece nadir olarak görülmektedir.

Anahtar sözcükler: Akut pankreatit, psödokist, spontan rüptür

Geliş tarihi/Received: June 15, 2013; Kabul tarihi/Accepted: May 13, 2014

\section{*Corresponding author:}

Dr. Ali Emre Atıcı, Genel ve Gastrointestinal Cerrahi Anabilim Dalı, Dr. Lütfi Kırdar Eğitim ve Araştırma Hastanesi, TR-34746 İstanbul. E-mail: aeatici@gmail.com 


\section{Introduction}

Pancreatic pseudocyst is a complication of acute or chronic pancreatitis. Diagnosis is accomplished most often by ultrasound, computed tomography or endoscopic retrograd cholangiopancreatography [1-3]. Most pseudocysts resolves spontaneously with supportive care, however chronic or larger pseudocysts are more likely to be symptomatic and may cause complications. The symptomatic or complicated pseudocysts [infected pseudocyst, gastric outlet or biliary obstruction, bleeding] are the main indications for percutaneous and endoscopic drainage procedures or surgery $[3,4]$. However, rarely $(3-$ $5 \%)$ pancreatic pseudocysts may drain into the adjacent hollow viscera, free peritoneal cavity or vascular system. Complications, treatment and prognosis can vary and lifethreatening bleeding can occur [5-8].

Many cases of spontaneous resolution of pancreatic pseudocyst have been reported in the literature, but most these spontaneous ruptures are associated with complications needing emergency surgical intervention. There are very few reports of uncomplicated rupture of pseudocysts in the literature [8-11]. Herein we present a case of pancreatic pseudocyst rupture into the duodenum, which resolved spontaneously without complications.

\section{Case report}

A 62-years old nonalcoholic diabetic male was admitted with an epigastric mass and postprandial fullness. In physical examination, the abdominal mass was completely fulled upper part of the abdomen. The patient had been treated with a diagnosis of acute pancreatitis by conservative management 3 months ago. On admission, laboratory studies were normal except for hyperglysemia. [hemoglobin, white blood cell, ast, alt, alp, ggt, amylase total protein, albumin, bun, creatinine, crp etc.] Ultrasonography showed an intraabdominal $15.5 \times 13.5 \mathrm{~cm}$ cystic mass near the left lobe of liver. Also computed tomography showed a large pseudocyst that containing gas and fluid material measuring $12 \times 10 \mathrm{~cm}$ in the lesser sac (Figure 1).

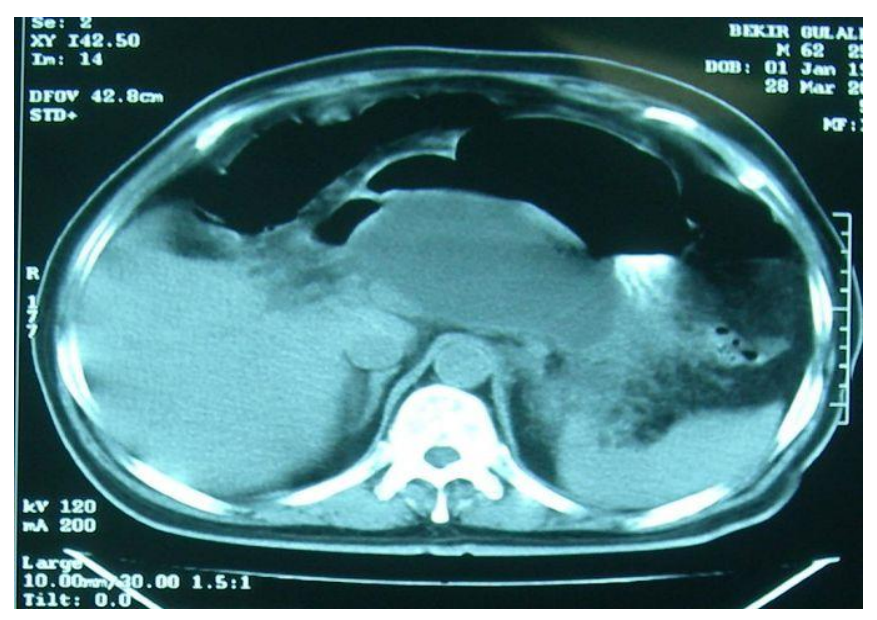

Figure 1. Pancreatic pseudocyts.

Ten days after admission, the patient complained of colic abdominal pain and severe diarrhae. At the same time the previously palpable epigastric mass disappeared. Computed tomography showed a little resolution of the pseudocyst in the lesser sac (Figure 2). 


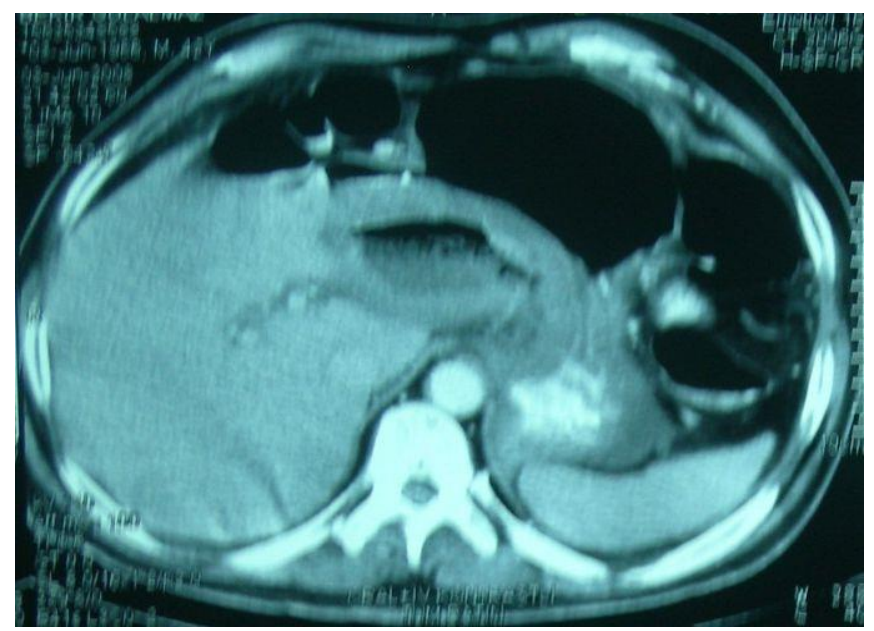

Figure 2. Spontaneous rupture of pancreatic pseudocyst-little regresion.

The dimensions of the residual lesion was 11x6 cm. Esophagogastroduodenoscopy revealed a small opening in the duodenum, through which a cream-like viscous material oozed into the lumen (Figure 3).

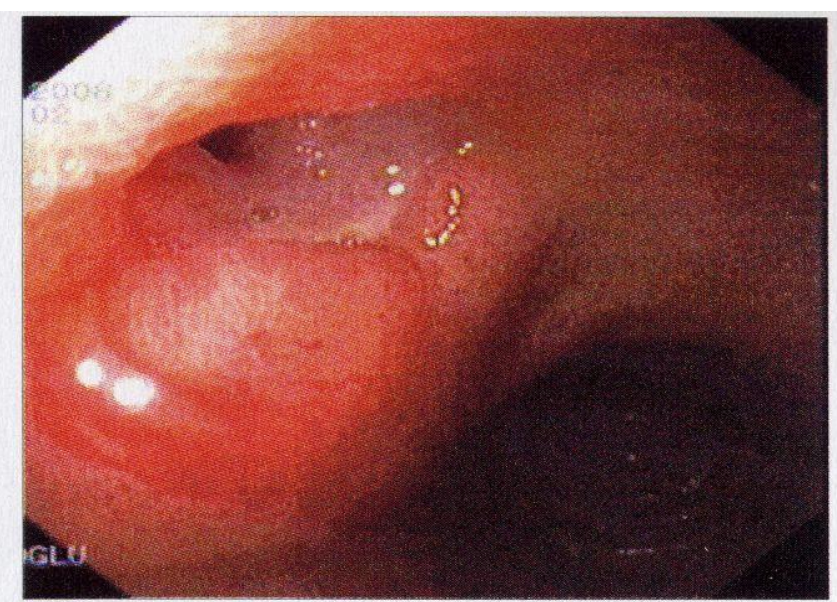

Figure 3. View of endoscopy-duodenal fistula.

He was treated nonsurgically and the symptoms gradually improved. For the next 72 hours, the patient's condition remained stable and he recovered without any complication. He was discharged home on the thirteen day of admission. After an uneventful follow up period of 5 months, control computed tomography showed a $3.5 \times 5.5 \mathrm{~cm}$ residual collection (Figure 4).

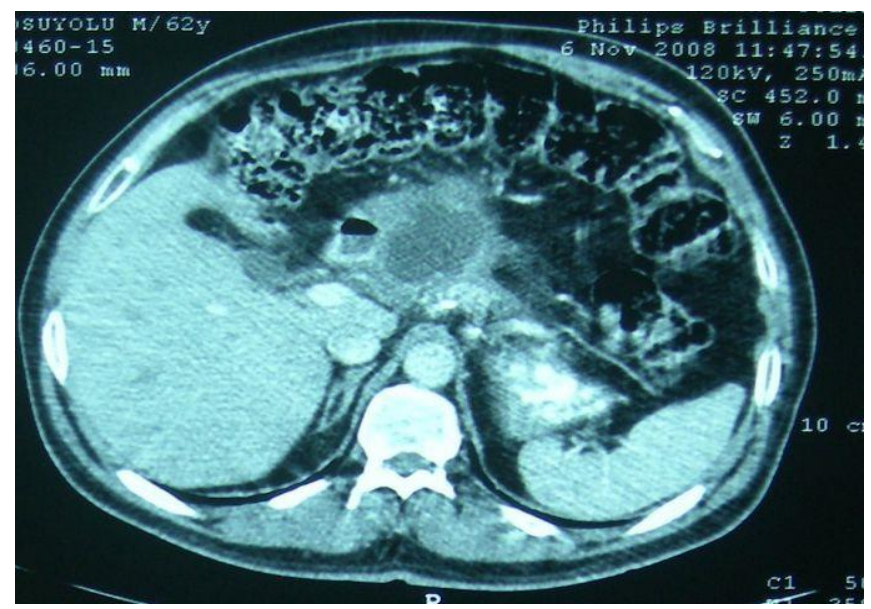

Figure 4. CT scan, five months later. 
He was followed up with regular intervals and he remained asymptomatic. One year later, the control tomography was completely normal (Figure 5).

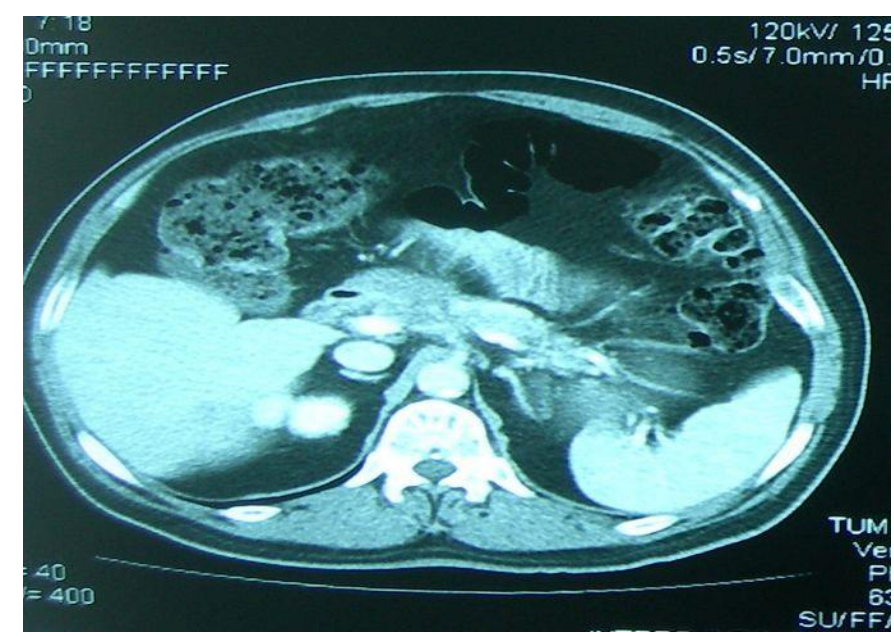

Figure 5. CT scan, one year later.

\section{Discussion}

Pseudocyst formation is one of the most common complications of acute pancreatitis. It usually develops over 1 to 4 weeks from the onset of pancreatitis [5]. Pseudocysts of the pancreas is a localized fluid collection that is rich in amylase and other pancreatic enzymes. The enzymatic and inflammatory action of this material evokes a reactive fibrosis in adjacent tissue. This results in formation of fibrous walls which enclose the fluid collection, but lacking an epithelial cover $[4,12]$. The most common symtoms are abdominal pain and mass, postprandial fullness, nausea and vomiting. Although they can be asymptomatic [4]. A variety of diagnostic tools including computed tomography, ultrasonography, endoscopic retrograde cholangiopancreaticography, biochemical analysis, cyst aspiration and cytology are used for the diagnosis of pancreatic pseudocysts. There is a consensus that computed tomography is mandatory for planning therapy and follow-up for a pancreatic pseudocyst [1]. The identification of a thickwalled, rounded, fluid-filled mass adjacent to the pancreas on abdominal scan in patient with a history of a acute or chronic pancreatitis is virtually pathognomonic for pancreatic pseudocyst [4]. The patient presented here had a pancreatic pseudocyst and history of recurrent acute pancreatitis 3 months ago. On admission, the patient was suffering from postprandial fullness and epigastric mass. We used computed tomography and ultrasonography for diagnosis and follow up of pancreatic pseudocyst.

The natural course of pseudocyst is not completely understood. Pseudocysts resolve spontaneously when the inflammation regresses but can remain for more than 6 months and require drainage procedures (percutaneous, endoscopic) or surgery [5, 12]. Mehta et al. $[9,13]$ found that pseudocyst less than $7.5 \mathrm{~cm}$ in diameter with a volume of less than $250 \mathrm{~mL}$ and with absence of internal debris were associated with spontaneous resolution over an average duration of 5 months whereas cyst larger than $7.5 \mathrm{~cm}$ in size or $>250 \mathrm{~mL}$ in volume needed surgical endoscopic intervention. Sometimes, the pseudocysts can drain to the gastrointestinal tract [stomach, duodenum, colon], biliary tract, adjacent structures, portal venous system, free abdominal cavity, renal collecting system or bronchial tree [9, 14]. Spontaneous rupture of the pancreatic pseudocyst has been reported in about $5 \%$ of patients with pancreatic pseudocyst secondary to pancreatitis $[6,12]$. Pseudocyst rupture apparently results from tryptic digestion of the wall. Pressure necrosis produced by the expanding cyst is an additional pathophysiologic factor. The rupture of pseudocyst into the abdominal cavity is of extreme severity. In contrast with, rupture of a pseudocyst into the gastrointestinal tract is often beneficial and may result in temporary or even 
permanent remission [12]. Nevertheless, mortality from this complication is high (about $50 \%$ ). Because many instances are associated with gastrointestinal hemorrhage or infection usually attends spontaneous drainage into the colon [12]. The incidence of bleeding pseudocyst in patients with chronic pancreatitis has been reported to be 6-10\% and mortality rate has been reported to range from $13 \%$ in treated patients to $90 \%$ in those who are untreated $[10,15]$. The development of any bleeding complications unquestionably demands some sort of radiological or surgical management $[10,15]$. When erosion of a pseudocyst occurs near the gastrointestinal tract and a fistula is formed, the patient's symptoms can vary, from no change to aggravation leading to death. [5] As high-density protein from the pseudocyst moves to the gastrointestinal tract through a fistula, patients manifest sudden clinical improvement with resolution of the pseudocyst after temporary symptoms of diarrhea, vomiting non-infected or infected cyst contents or blood and hematochezia $[5,16,17]$. In this case, ten days after admission, the patient complained colic abdominal pain and severe diarrhae. Also epigastric mass was disappeared in physical examination but did not other complications such as gastrointestinal tract bleeding and infection. Follow up abdominal computed tomography examination showed resolution of the pseudocyst and esophagogastroduodenoscopy revealed a small hole in the duodenum, through which a cream-like viscous material oozed into the lumen. The locations in the gastrointestinal tract most vulnerable to fistula formation are the transverse colon and the splenic flexure of colon, followed by the duodenum $[5,18]$. The small intestine, stomach and esophagus are uncommon locations $[5,6,16]$. The patient does not require surgery if the pseudocyst resolves as a result of fistula formation. Conservative management of pancreatic pseudocyst will often result in complete resolution [19]. However, spontaneous rupture of pseudocyst into the colon have a high risk of infection and rarely close spontaneously and usually necessitates emergency surgery $[5,18]$. The patient presented here was monitored with conservative procedures and did not require surgical treatment. He was discharged home and followed up with regular intervals. One year later, the patient remains asymptomatic and the control tomography was completely normal.

In conclusion, pancreatic pseudocysts are serious problems and spontaneous resolution of them without complication is seen very rarely.

\section{References}

1. Aghdassi A, Mayerle J, Kraft M, Sielenkämper AW, Heidecke CD, Lerch MM. Diagnosis and treatment of pancreatic pseudocysts in chronic pancreatitis. Pancreas 2008; 36: 105-12.

2. Uzun Y, Beyler AR, Bozkaya H, Ormeci N, Bahar K, Karayalcin S, Goren A, Dokmeci A. Medical drainage of pancreatic pseudocysts. Turk J Gastroenterol 1998; 9: 259-63.

3. Kapan M, Kapan S, Durgun AV, Goksoy E, Perek S. Current approach in pancreatic pseudocysts: Retrospective analysis of 39 cases in the light of the literature. Journal of Aegean Med (Ege Tip Dergisi) 2004; 43: 175-80.

4. Habashi S, Draganov PV. Pancreatic pseudocyst. World J Gastroenterol 2009; 15: 38-47.

5. Yeom HJ, Yi SY. Spontaneous resolution of pancreatic gastric fistula. Dig Dis Sci 2007; 52: 561-4.

6. Takayama T, Kato K, Sano H, Katada N, Takeichi M. Spontaneous rupture of a pancreatic pseudocyst into the portal venous system. AJR 1986; 147: 935-6.

7. Oztaş E, Ozin YO, Etik D, Oguz D, Parlak E, Sasmaz N. Spontaneus drainage of pancreatic pseudocyst into the stomach: Diagnosis made simultaneously with the endosonographic examination. Endoscopy 2009; 17: 82-3.

8. Somani PO, Jain SS, Shah KD, Khot AA, Rathi MM. Uncomplicated spontaneous rupture of pancreatic pseudocyst into stomach: A case report. World J Gastrointest Endosc 2013; 5: 461-4. 
9. Mir MF, Shaheen F, Gojwari TA, Singh M, Nazir P, Ahmad S. Uncomplicated spontaneous rupture of the pancreatic pseudocyst into the gut-CT documentation: A series of two cases. The Saudi Journal of Gastroenterology 2009; 15: 135-6.

10. Urakami A, Tsunoda T, Kubozoe T, Takeo T, Yamashita K, Imai H. Rupture of a bleeding pancreatic pseudocyst into the stomach. J Hepatobiliary Pancreat Surg 2002; 9: 383-5.

11. Willard MR, Schafer HA. Resolution of pancreatic pseudocyst by spontaneous rupture into stomach. South Med J 1982; 75: 618-20.

12. Clements JL, Bradley EL, Eaton SB. Spontaneous internal drainage of pancreatic pseudocysts. Am J Roentgenol 1976; 126: 985-91.

13. Mehta R, Suva Rana D. Natural course of asymptomatic pancreatic pseudocyst: A prospective study. Indian J Gastroenterol 2004; 23: 140-2.

14. Tanaka A, Takeda R, Utsunomiya H. Severe complications of mediastinal pancreatic pseudocyst: Report of esophago-bronchial fistula and hemothorax. J Hepatobiliary Pancreat Surg 2000; 7: 85-91.

15. Stabile BE, Wilson SE, Debas HT. Reduced mortality from bleeding pseudocysts and pseudoaneurysms caused by pancreatitis. Arch Surg 1983; 118: 45-51.

16. Poole GV, Wallenhaupt SL. Massive rectal bleeding from colonic fistula in pancreatitis. Arch Surg 1984; 119: 732-5.

17. Doberneck RC. Intestinal fistula complicating necrotizing pancreatitis. Am J Surg 1989; 158: 581-4.

18. Ho HS, Frey CF. Gastrointestinal and pancreatic complications associated with severe pancreatitis. Arch Surg 1995; 130: 817-23.

19. Conway WC, Brown KL, Sugawa C, Lucas CE. Spontaneous gastric decompression of peripancreatic collection. The American Journal of Surgery 2008; 196: 29-30. 